\title{
PENGEMBANGAN POTENSI BUDAYA EKOWISATA MELALUI PEMBERDAYAAN MASYARAKAT DESA WISATA CANDIREJO BOROBUDUR JAWA TENGAH
}

Syaiful Ade Septemuryantoro ${ }^{1}$

${ }^{l}$ Universitas Dian Nuswantoro, Semarang, Indonesia, syaiful.ade@dsn.dinus.ac.id

\begin{tabular}{|c|c|}
\hline & ABSTRAK \\
\hline $\begin{array}{c}\text { Histori Artikel } \\
\\
\text { Submitted: } \\
\text { 27 Juli } 2020 \\
\text { Reviewed: } \\
2 \text { Oktober 2020 } \\
\text { Accepted: } \\
\text { 12 Oktober 2020 } \\
\text { Published: } \\
\text { 15 November 2020 }\end{array}$ & $\begin{array}{l}\text { Penelitian yang dilakukan bertujuan mengetahui perkembangan } \\
\text { ekowisata di Desa Candirejo. Pengembangan ekowisata di Desa } \\
\text { Candirejo bertujuan untuk memberikan dampak positif bagi masyarakat } \\
\text { Candirejo yaitu menjadi sumber tambahan pendapatan masyarakat. } \\
\text { Penelitian ini menggunakan teknik deskriptif analitik, metode } \\
\text { pendekatan kualitatif adalah cara pengumpulan data melalui warga desa } \\
\text { Candirejo. Teknik wawancara dan pengumpulan dokumen merupakan } \\
\text { cara untuk mendapatkan data penelitian ini. Teknik pengambilan } \\
\text { sampel dalam penelitian ini menggunakan teknik purposive sampling, } \\
\text { kemudian data yang akan dikumpulkan berupa observasi kepada }\end{array}$ \\
\hline
\end{tabular}

Kata Kunci: pemberdayaan, desa wisata, potensi

\section{DEVELOPING ECOTOURISM AND CULTURE POTENTIALS THROUGH THE EMPOWERMENT OF RESIDENT OF CANDIREJO BOROBUDUR CENTRAL JAVA}

\section{ABSTRACT}

The research that will be proposed has the objective of identifying the development of ecotourism in the Candirejo village. The development of ecotourism in the Village of Candirejo has the goal of making a positive impact in the environment of Candirejo. Positive impact expected by the community and identification of ecotourism development is expected to be a source of income of the candirejo village. This research uses descriptive analytical technique, qualitative approach method is a way to get data and collecting data through candirejo villagers. Interview techniques and document collection are ways to get data this research. The technique used to take samples in the study is using purposive sampling technique,then the data to be collected in the form of observation to the community, interviews and document review. Community empowerment in the village of Candirejo has been going well. Candirejo Village cooperates with related agencies.the collaboration was carried out to develop the potential of the village.

Keywords : village tourism empowerment, tourism potential, culture

\section{PENDAHULUAN}

Desa Candirejo Borobudur menyimpan sejumlah potensi diantaranya potensi kebudayaan dan kesenian asli seperti Tarian Jawa, Jatilan, Saparan Gatholoco,
Kubrosiswa. Berbagai potensi yang ada di desa Candirejo tersebut dapat dikemas serta dikelola oleh masyarakat sekitar menjadi suatu jenis pemberdayaan masyarakat melalui Koperasi yang dikelola juga oleh masyarakat. Koperasi desa Candirejo 
menjadi suatu bentuk badan usaha desa yang mengelola semua kegiatan wisata yang akan ditawarkan oleh wisatawan. Upaya pemetaan yang akan dilakukan meliputi kawasan desa wisata Candirejo yang berupa pemetaan sumber potensi wisata di desa Candirejo, kemudian program yang berkaitan dengan promosi wisata serta mengadakan pelatihan yang menunjang kegiatan pemberdayaan masyarakat sekitar. Selain itu kerjasama antar desa wisata dan lembaga perguruan tinggi perlu dilakukan guna memperkenalkan potensi desa wisata Candirejo Magelang, dengan adanya program promosi yang berkaitan erat dengan pemberdayaan masyarakat diharapkan masyarakat mampu meningkatkan potensi diri.

Adapun beberapa faktor yang mendukung bahwa desa wisata Candirejo dapat dikembangkan antara lain potensinya masih bisa dikembangkan, secara letak desa wisata Candirejo berdekatan dengan pusat pemerintahan, dekat dengan sumber daya yang dibutuhkan demi mengembangkan potensi diri masyarakat di desa Candirejo Borobudur Magelang. Peran masyarakat yang aktif menjadikan desa wisata Candirejo dapat berkembang, selain itu terdapat kendala yang ditemui di lokasi desa Candirejo antara lain berkaitan dengan dana baik secara sukarela dan bantuan dari pemerintah, terbatasnya sumber daya manusia (SDM), serta lemahnya kemampuan bahasa asing masyarakat di desa Candirejo Borobudur. Lemahnya kemampuan bahasa menjadikan komunikasi dengan tamu asing menjadi terhambat sehingga perlu pelatihan bahasa asing. Melakukan upaya memberdayakan peran dan potensi masyarakat desa Candirejo tentunya akan berdampak secara langsung pada sektor ekonomi, sektor sosial, dan sektor budaya. (https://www.potensijateng.com/, diakses 1 Oktober 2020).

Dampaknya pada sektor ekonomi adalah mampu meningkatkan pendapatan masyarakat dan menyediakan lapangan kerja seluas mungkin bagi masyarakat sekitar. Mata Pencaharian yang dahulunya sebagai petani dapat berkembang menjadi local guide, mendirikan homestay, serta membuka home industry dengan memanfaatkan sumber daya alam di desa wisata Candirejo Borobudur Magelang. Selain sektor ekonomi terdapat dampak dari sektor sosial budaya antara lain kegiatan promosi yang dilakukan untuk lebih mengenalkan potensi masyarakat sekitar serta perlu dilakukan pelatihan soft skill kepada masyarakat desa Candirejo supaya kemampuan masyarakat dapat berkembang guna mengelola potensi yang terdapat di desa Candirejo Borobudur Magelang. Pemberdayaan masyarakat desa wisata Candirejo memberikan sebuah peluang yang dirasa penting dalam memberikan kesempatan dan peluang dalam partisipasi peran serta masyarakat sekitar dalam berpartisipasi di komunitas lokal serta mampu melibatkan diri dalam sebuah proses pengambilan keputusan yang nantinya dapat dinikmati oleh seluruh masyarakat desa wisata Candirejo Borobudur Magelang. Salah satu upaya yang dilakukan oleh berbagai pihak tersebut adalah dengan cara pengembangan komunitas. Adanya potensi budaya pada destinasi wisata mampu mendorong perekonomian warga setempat (Septemuryantoro, 2017).

Hal tersebut juga disebutkan oleh Widayanti (2012) bahwa emansipasi komunitas adalah perhatian publik dan dihargai seperti itu pendekatan yang tepat untuk mengatasi masalah sosial, khususnya kemiskinan, yang dilaksanakan berbagai unsur mulai dari pemerintah, dunia usaha dan masyarakat hingga Organisasi masyarakat sipil. Aksi pemberdayaan masyarakat merupakan salah satu upaya memberikan kekuatan atau kekuatan kepada masyarakat untuk keluar dari masalah. Aksi pemberdayaan masyarakat juga harus mandiri sehingga mereka dapat menghadapi berbagai tantangan dalam hidup mereka. Adanya globalisasi yang semakin menggerus kebudayaan masyarakat lokal harus tetap mampu mempertahankan kebudayaan lokal dengan cara tetap melestarikan budaya peninggalan turun-temurun. 
Selain itu masyarakat Candirejo dapat menikmati keuntungan dengan adanya perkembangan industri pariwisata yang saat ini telah digencarkan oleh Kementerian Pariwisata. Pelaksanaan Pemberdayaan mempunyai tujuan penting yaitu tentang upaya memaksimalkan potensi masyarakat sekitar maupun masyarakat desa wisata Candirejo dengan mengisi berbagai aspek pembangunan pariwisata di daerah maupun nasional. Masyarakat tentunya diposisikan sebagai penentu kebijakan yang ada di lingkungan desa Candirejo bukan sebagai penonton yang hanya terlibat dari kepentingan di luar desa tersebut. Keterlibatan masyarakat merupakan suatu keharusan yang dapat dimulai dari proses perencanaan sampai dengan pelaksanaan yang nantinya menjadikan peran penting masyarakat desa wisata Candirejo dalam pengambil keputusan. Melalui kebijakan yang dilakukan oleh DINPORA Kabupaten Magelang tentunya mempunyai tujuan dalam melestarikan sumber daya alam yang dimiliki oleh desa Candirejo sehingga menjadikan desa wisata Candirejo sebagai magnet baru sebagai sumber utama maupun magnet sebagai sumber daya tarik kepada calon wisatawan dan tentunya meningkatkan sumber penghasilan masyarakat desa Candirejo Kabupaten Magelang, dengan adanya potensi yang dikembangkan akan selaras dengan tingkat kesejahteraan masyarakat desa Candirejo dalam upaya meningkatkan perekonomian desa Candirejo serta meningkatkan pemerintah Kabupaten berkitan dengan pajak yang nantinya akan dikelola sebagai bentuk upaya pelestarian sumber daya alam di desa Candirejo.

\section{LITERATUR REVIEW}

Menurut UU Nomor 90 Tahun 1990 bahwa sejatinya pariwisata merupakan jenis kegiatan antara lain : Wisata merupakan sebuah bentuk perjalanan yang akan dilakukan secara sukarela dalam menikmati daya tarik pariwisata dan objek wisata, Para wisatawan merupakan sekelompok orang maupun individu yang melaksanakan kegiatan pariwisata, Pariwisata merupakan aspek yang berkaitan erat dengan wisata dalam hal ini termasuk juga pemanfaatan objek serta objek wisata yang menjadi daya tarik wisata dan usaha yang saling berkaitan, Pariwisata merupakan hal yang erat hubungannya dengan kegiatan penyelenggaraan pariwisata, Kepariwisataan merupakan salah satu bentuk kegiatan yang berhubungan erat dengan penyelenggaraan pariwisata, Usaha kepariwisataan merupakan bentuk kegiatan yang bertujuan menyelenggarakan kegiatan jasa pariwisata maupun menyediakan ataupun mengusahakan objek serta daya tarik wisata, usaha pariwisata serta usaha lain yang terkait dalam bidang pariwisata, Daya tarik dan objek pariwisata merupakan sasaran wisata, Kawasan terintegrasi dengan pariwisata merupakan kawasan yang luasnya tertentu yang dibangun untuk pemenuhan pariwisata

Sedangkan menurut UU Republik Indonesia Nomor 10 Tahun 2009 yang menyatakan bahwa kepariwisataan membentuk beberapa istilah antara lain :

Wisata merupakan bentuk kegiatan usaha perjalanan wisata yang akan dilaksanakan baik secara kelompok maupun secara individu yang mempunyai tujuan antara lain sebagai arena rekreasi bertujuan untuk mengunjungi tempat yang mempunyai tujuan untuk rekreasi, pengembangan pribadi serta mempelajari bermacam keunikan yang menjadi daya tarik wisata yang dikunjungi dalam waktu sementara.

Pariwisata merupakan bentuk kegiatan wisata yang fasilitasnya disediakan oleh masyarakat, usahawan atau pengusaha serta dinas yang terkait di lokasi wisata tersebut.

Destinasi wisata dapat dikatakan sebagai destinasi pariwisata dimana kondisi alam baik secara geografis berada dikawasan wilayah administrasi sehingga daya tarik wisata maupun fasilitas umum, dan fasilitas pariwisata dengan adanya aksesbilitas yang baik dari masyarakat yang saling melengkapi sehingga terwujudnya kepariwisataan. Sedangkan menurut Hadiwijoyo (2012) bahwa desa wisata harus memenuhi 
persyaratan adalah sebagai berikut :Mempunyai aksesbilitas yang baik sehingga wisatawan dengan mudah mengunjungi lokasi tersebut dengan menggunakan sarana transportasi yang beragam. Mempunyai obyek yang menarik seperti alam yang asri, seni budaya yang indah, legenda tempat tersebut, makanan khas dan siap untuk dikembangkan sebagai atraksi wisata. Era globalisasi yang mampu mengubah zaman menjadikan suatu jenis kebudayaan bahkan dianggap telah ketinggalan zaman oleh masyarakat. Terdapat sebagian dari masyarakat yang patuh dalam mempertahankan serta mentradisikan salah satu peninggalan nenek moyang. (Septemuryantoro, 2020).

Masyarakat serta aparatur desa dapat menerima dan memberikan dukungan yang tinggi terhadap desa wisatawan serta wisatawan yang berkunjung di desa wisata. Mempunyai keamanan yang baik di desa tersebut. Mempunyai akomodasi, sarana telekomunikasi serta adanya tenaga kerja yang handal dan memadai. Mempunyai iklim yang sejuk atau berhawa dingin. Mempunyai hubungan yang baik dengan objek wisata lain yang telah dikenal sebelumnya oleh masyarakat sekitar dengan desa wisata yang mencerminkan wilayah pedesaan dengan keseluruhan suasana desa dengan keaslian sumber daya di pedesaan. Keadaan sosial dan budaya, adat istiadat dan arsitektur bangunan dan struktur tata ruang desa dan menjadi sebuah potensi yang mampu dikembangkan yang nantinya termasuk ke dalam komponen kepariwisataan, sedangkan menurut Suwantoro (2004) menjelaskan konsep pemberdayaan yang terdiri dari tiga komponen diantaranya : Pengaturan yang memungkinkan; Memberdayakan komunitas lokal; Dukungan sosial-politik.

Menurut Muljadi (2012) menyebutkan bahwa desa wisata merupakan pengembangan dari suatu kawasan desa yang Realitas tidak mengubah apa yang sudah ada, tetapi lebih mungkin dalam mengembangkan potensi desa yang ada dengan memanfaatkannya kemampuan elemen desa yang berfungsi sebagai atribut produk pariwisata skala kecil dalam rangkaian kegiatan atau dan dapat menyediakan dan memenuhi kegiatan pariwisata kebutuhan perjalanan baik dari segi daya tarik maupun cara pandangnya serta struktur pendukung. Sedangkan menurut Septemuryantoro (2020) mengatakan bahwa kawasan akulturasi budaya mmapu mengkayakan potensi desa wisata. Menurut Ismayanti (2013) bahwa desa wisata merupakan daerah pedesaan atau daerah yang dapat digunakan di pangkalan kapasitas berbagai elemen yang memiliki atribut produk pariwisata terintegrasi, dimana desa menawarkan semua suasana pedesaan yang bertema keaslian pedesaan, baik dari segi kehidupan, sosial budaya dan ekonomi serta adat istiadat yang memiliki ciri khas arsitektur dan struktur desa menjadi rangkaian kegiatan dan kegiatan pariwisata. Mampu mempertahankan potensi budaya di suatu daerah sehingga kebudayaan tersebut akan lestari dan tidak tergerus oleh kemajuan jaman (Septemuryantoro, 2020).

\section{METODE}

Metoda penelitian menggunakan teknik kualitatif yang bersifat analitik deskriptif, metode ini sangat tepat untuk dapat mengkaji bentuk pemberdayaan desa. Lokasi yang dipilih untuk penelitian adalah desa wisata Candirejo Borobudur Magelang. Metode wawancara digunakan pada penelitian yang dilakukan secara mendalam melalui teknik wawancara kepada masyarakat desa wisata Candirejo, kemudian observasi serta pengumpulan dokumen terhadap para tokoh yang terlibat di desa tersebut. Lokasi yang diambil pada penelitian ini adalah di Desa Wisata Candirejo dan waktu penelitian dimulai pada bulan November 2019 dengan subjek penelitian adalah informan dari Masyarakat Ketua Tanker Borobudur dan pihak yang terkait. Teknik analisa data pada penelitian pemberdayaan pada masyarakat desa Candirejo mengacu pada pendapat Milles \& Huberman dalam Sugiyono (2010) dimana teknik analisa ini terbagi atas 3 bagian antara lain : Reduksi data, yaitu 
proses pemilihan, penyederhanaan, dan memfokuskan terhadap hal-hal penting yang dibutuhkan untuk melakukan suatu penelitian. Sehingga data yang sudah direduksi akan membantu memberikan gambaran yang jelas dan mempermudah dalam melakukan penelitian.

Penyajian data, yaitu penjelasan dari kumpulan informasi yang tersusun secara rapi dan mudah dimengerti sehingga memudahkan untuk melakukan penarikan kesimpulan.

Penarikan kesimpulan, yaitu tahap akhir pada proses analisis data yang dimulai dari pengumpulan data, penyajian data hingga reduksi data. Kesimpulan dari penelitian ini mengacu pada rumusan masalah yang akan dicapai

\section{HASIL DAN PEMBAHASAN}

\section{Hasil Identifikasi Masyarakat Desa Candirejo sebelum dilakukan Pemberdayaan}

Adapun beberapa unsur yang akan diamati pada penelitian ini sebelum serta setelah dilakukan pemberdayaan masyarakat desa Candirejo menunjukkan bahwa terdapat aspek antara lain : aspek lingkup masyarakatnya, kemudian jenis pekerjaan yang ditekuni oleh masyarakat sekitar, kemudian hasil pendapatan masyarakat sekitar dalam bentuk aspek ekonomi. Faktor lingkungan menjadikan salah satu aspek yang sangat penting karena pada awalnya masyarakat desa wisata di Candirejo kurang berpartisipasi aktif dalam pengembangan di desanya. Adapun faktor yang mempengaruhi tingkat partisipasi masyarakat yaitu masyarakat belum terbiasa dengan arahan anjuran dari pemerintah Kabupaten atau pemerintah daerah yang belum mencakup keseluruhan untuk kemajuan desa wisata tersebut. Kegiatan pemberdayaan masyarakat desa dilakukan dengan menggunakan pendopo sebagai tempat berkumpul masyarakat dan masyarakat desa tersebut mempunyai antusias yang sangat besar terhadap pengetahuan yang baru, akan tetapi tipikal masyarakat desa yang sedikit kaku merupakan salah satu bentuk hambatan akan kegiatan pemberdayaan yang dilakukan oleh pemerintah setempat, karena adanya pelatihan yang belum merata terhadap desa wisata tersebut ditinjau dari aspek pekerjaan yang ada di desa Candirejo Magelang. Mayoritas masyarakat desa wisata Candirejo Magelang umumnya bekerja sebagai petani yaitu profesi yang telah dilakukan turun temurun dari nenek moyangnya dengan adanya profesi sebagai buruh tani ataupun petani masyarakat desa Candirejo umumnya mengandalkan sawah atau ladang mereka untuk dijadikan sumber penghasilan. Karena letak geografis desa wisata Candirejo ada pada kondisi alam yang sangat cocok untuk pertanian selain itu sebagian masyarakat desa Candirejo banyak yang berprofesi sebagai Pegawai Negeri Sipil, aparat, Tentara Nasional Indonesia, Polisi Republik Indonesia serta usaha lain yang menjadikan desa Candirejo sebagai desa yang beragam profesi selain petani. Di sekitar Desa tersebut pada dasarnya masyarakat yang mempunyai potensi yang sangat tinggi terhadap Sumber Alam maupun SDM (sumber daya manusia) dan jika potensi tersebut dikembangkan maka akan meningkatkan pola pekerjaan maupun pendapatan yang ada di desa wisata Candirejo. Ditinjau dari aspek profesi pekerjaan masyarakat desa Candirejo yaitu petani dan berdagang sehingga apabila masyarakat desa wisata Candirejo melakukan aktivitas hanya di lingkup sekeliling mereka saja. aspek lingkup masyarakatnya, kemudian jenis pekerjaan yang ditekuni oleh masyarakat sekitar, kemudian hasil pendapatan masyarakat sekitar dalam bentuk aspek ekonomi menjadikan ide untuk mendirikan desa Candirejo sebagai salah satu destinasi wisata yang berdekatan dengan Candi Borobudur. Menurut Anwas (2013) bahwa melakukan pemberdayaan terhadap masyarakat tentunya harus berkesesuaian dengan kekuasaan.

Desa ini layak untuk dijadikan destinasi wisata karena letaknya yang sangat strategis sebelum Candi Borobudur. Selain itu kondisi geografis Candi Rejo yang letaknya 
berdekatan dengan Candi Borobudur sehingga desa ini mempunyai potensi yang dapat dikembangkan antara lain dilihat dari segi SDM dan sumberdaya alamnya dan akhirnya memungkinkan untuk dikembangkan. Selanjutnya didiskusikanlah siapa yang bertugas mencari potensi di masing-masing Dusun, dengan kondisi alam desa wisata di Indonesia memiliki potensi alam agrowisata, Tani, kesenian, serta home industri kemudian adanya potensi dari lokal dan dan adanya penginapan yang disediakan oleh penduduk asli.

\section{Hasil Identifikasi Masyarakat Desa Candirejo setelah dilakukan Pemberdayaan}

Dibentuknya pokdarwis di desa wisata Candirejo yaitu memperkenalkan kepada masyarakat desa tersebut bahwa desa ini akan dijadikan desa wisata, karena mempunyai berbagai macam bentuk kesenian asli daerah tersebut dan kemudian industri rumahan serta aspek lain yang harus dikembangkan. Apabila ditinjau dari aspek sebelum pemberdayaan dan setelah dilakukan upaya pemberdayaan terhadap masyarakat desa tersebut menciptakan terjadinya bentuk perubahan ke arah yang lebih baik khusus pada masyarakat desa tersebut. Pemberdayaan masyarakat di desa wisata Candirejo dilakukan dengan pelatihan maupun bantuan dari pemerintah maupun dari instansi atau akademisi maka tingkat partisipasi masyarakat desa wisata Candirejo meningkat. Hal ini dapat dilihat warga mulai antusias untuk mengikuti kegiatan tersebut dan terlibat aktif dalam setiap kegiatan pemberdayaan di desa Candirejo Magelang, sehingga dapat dikatakan pemberdayaan itu berhasil karena mampu mengubah mental orang-orang yang dulunya apatis namun sesudah diadakan atau dibentuk pokdarwis maka pola pikir masyarakat menjadi lebih terasah dan mengikuti setiap kegiatan yang dilakukan oleh instansi terkait dalam pemberdayaan masyarakat.

Apabila ditinjau dari golongan pekerjaan, sesudah dilaksanakan usaha pemberdayaan masyarakat desa wisata Candirejo nampak sedikit perbedaan yang terjadi apabila dilihat dari jenis mata pencaharian yang dahulu sebagai petani desa, Pegawai Negeri Sipil, Tentara Nasional Indonesia, buruh, maupun sektor lain dan setelah pemberdayaan mulai berkembang maka masyarakat desa wisata Candirejo bergerak di Sentral pariwisata seperti lokal guide, homestay kemudian sentra-sentra industri yang mengedepankan potensi kekayaan alam yang telah tersedia di desa tersebut. Kuliner merupakan salah satu bentuk jenis usaha yang ikut menyumbangkan tenaga kerja untuk kebutuhan memproduksi kuliner salah satu contoh adalah kuliner slondok atau kerupuk yang terbuat dari ketela. Apabila ditinjau dari aspek pendapatan ekonomi setelah ada pemberdayaan masyarakat yang ada di desa wisata Candirejo, umumnya berdampak pada pendapatan yang diperoleh oleh masyarakat sekitar desa wisata Candirejo. Pendapatan masyarakat desa Candirejo menjadi meningkat karena semakin banyaknya pemberdayaan yang ada atau dilakukan oleh pemerintah maupun oleh instansi atau akademisi, maka ditinjau dari segi pendapatan terjadi kenaikan income masyarakat sekitar adapun contohnya pendapatan sebagai lokal guide kemudian sebagai penarik Andong, homestay dan lain sebagainya. Dengan adanya peningkatan aspek ekonomi yang ada di desa wisata Candirejo maka perputaran ekonomi juga semakin besar dalam hal wisata.sama halnya dengan pendapat komponen desa wisata harus mempunyai keunikan, keaslian, Keistimewaan, Lokasinya berdekatan dengan kawasan alam yang luar biasa, serta adanya interaksi dengan kelompok atau masyarakat berbudaya yang secara inheren menarik ketertarikan pengunjung, memiliki kemampuan berkembang baik (Gima, 2013)

\section{Jenis Program Pemberdayaan untuk Masyarakat Candirejo}

Penginapan Penduduk Lokal, saat ini Desa Candirejo mempunyai suatu bangunan yang dahulunya kosong karena banyak dari anggota keluarga merantau ke luar desa sehingga kemudian dibentuklah penginapan 
yang dimiliki oleh penduduk desa dan kebanyakan dari penginapan tersebut adalah kelas ekonomi yang memiliki kamar tidur serta kamar mandi yang terpisah dan terletak di luar ruangan sehingga menimbulkan kesan bahwa wisatawan dapat menikmati ataupun berkesan untuk kembali ke alam. Dengan adanya homestay menjadikan serta dapat bersosialisasi dengan pemilik homestay. Penginapan lokal penduduk bukanlah hotel yang mewah tetapi dengan adanya warga yang tergabung ke dalam paguyuban homestay yang nantinya akan dikelola oleh koperasi Desa maka pemilik homestay mempunyai kesempatan untuk meningkatkan income. Pendapatan yang dihasilkan dari menyewakan Homestay dengan tema kembali ke alam, maka homestay akan mengajak kembali wisatawan untuk kembali menikmati suasana alam tempo dulu. Penduduk yang menyewakan kamar kemudian mendapatkan pelatihan dari instansi terkait maupun dari kelompok wisata antara lain: hospitality kemudian menu atau masakan tradisional khas dari desa wisata Candirejo, kemudian bagaimana menyiapkan food and hygiene sanitation kemudian menyiapkan keperluan untuk tamu.

Pemandu Lokal Desa wisata Candirejo Magelang mempunyai local guide merupakan anggota dari pokdarwis dan masyarakat sekitar desa wisata Candirejoo sebagai bentuk pemberdayaan masyarakat yang ada serta membuka lapangan pekerjaan bagi masyarakat. Sekitar lokasi yang ada di desa wisata Candirejo umumnya masih kekurangan tenaga pemandu wisata baik dalam segi jumlah maupun kemampuan untuk menjelaskan kepaa wisatawan, adapun jumaj pemandu yang dimiliki adalah 15 orang yang bertugas sebagai pemandu lokal serta 8 orang yang bertugas pada area sungai. Pemerintah Daerah hanya melakukan kegiatan pelatihan atau pembinaan yang dilakukan hanya 2 kali dalam setahun sehingga masih sangat kurang untuk ilmu yang diajarkan untuk para tour guide, dengan kurangnya pembinaan kepada tour gaet maka melayani wisatawan yang akan berkunjung tentunya kurang maksimal karena keterbatasan pengetahuan. Hal ini disebabkan karena umumnya para tour guide yang ada di desa wisata Candirejo memiliki tingkat pendidikan yang rendah sehingga harus dilakukan pelatihan kelanjutan untuk meningkatkan kualitas sumber daya manusia bagi para lokal

Penyewaan sepeda gunung yang terdapat di desa wisata Candirejo; banyaknya wisatawan yang memilih menaikidan memilih paket wisata yang ditawarkan yaitu paket wisata mengelilingi desa dengan menggunakan sepeda onthel, akan tetapi umumnya penyewa homestay meminjam sepeda dari induk homestay yang ditinggali sehingga muncul ide kerjasama dengan warga sekitar yang berdekatan untuk bantuan sepeda, sehingga dengan adanya bantuan sepeda yang dikelola oleh koperasi dapat membuat paket untuk wisatawan, tentunya wisatawan merasa senang karena kembali ke alam dengan menggunakan sepeda onthel.

Agrowisata dan agrotani, adanya kegiatan pengembangan komunitas desa wisata Candirejo di bawah pengawasan koperasi desa wisata Candirejo; dalam hal ini kegiatan pertanian seperti membaca sawah menanam padi Mina Tani akan langsung diresapi dengan petani lokal, karena anggota pertanian umumnya membangunkan komunitas karena menyadarkan penduduk setempat dipengaruhi oleh modernisasi, sehingga dengan adanya kegiatan agrowisata dan aku Tani menunjukkan bahwa Aktivitas ini ni mampu menjadikan wisatawan bersyukur karena dengan adanya Agro Tani dan agrowisata dilakukan oleh petani wisatawan dapat bersyukur dapat mengisi perut mereka dengan nasi yang dihasilkan oleh para petani.

Kesenian asli desa Candirejo, Kesenian asli desa Candirejo memiliki kelompokkelompok yang berjumlah lebih dari 10 kelompok kesenian, adapun kesenian asli desa yang akan ditonjolkan sebagai kesenian yang ditawarkan kepada wisatawan antara lain kesenian wayang, krawitan, ketoprak, Jathilan, kesenian topeng, gatholoco, solawatan, serta marawis, dengan adanya 
jenis kesenian asli masih dimiliki oleh masyarakat desa Candirejo dan masih terpelihara karena masyarakat desa wisata Candirejo melestarikan budaya yang ada di desa wisata tersebut agar tetap Lestari dan tidak tergerus oleh mordenisasi.

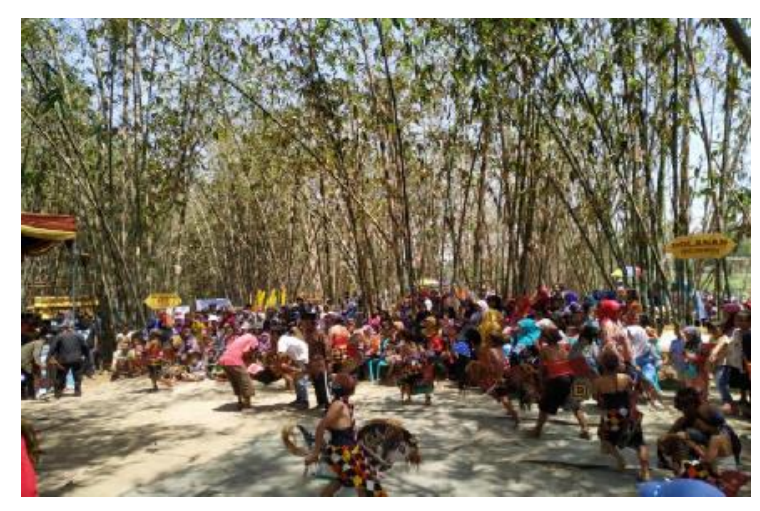

Gambar 1. Kesenian Tradisional Sumber: Data primer (2019)

Pemanfaatan Koperasi Desa, koperasi merupakan salah satu tempat yang sangat bermanfaat untuk penduduk desa wisata Candirejo baik maupun perorangan maupun kelompok. Koperasi desa wisata Candirejo mampu memberdayakan masyarakat desa tersebut dengan adanya rapat tahunan koperasi Desa. Adapun jenis-jenis usaha wisata yang diajarkan serta yang akan diberikan untuk wisatawan tersebut kemudian dikemas dengan sangat baik yang melingkupi seluruh aspek potensi yang ada di desa tersebut, wisatawan yang telah mengenal desa tersebut diharapkan akan meningkatkan pendapatan penduduk setelah adanya paket wisata yang tentunya beragam dan dikemas secara apik.

\section{Paket Wisata Kebudayaaan}

Andhong Tour, paket yang ditawarkan untuk wisatawan adalah menikmati andhong/ dokar tour yang mengelilingi desa wisata dan wisatawan akan merasakan atmosfer dari penduduk sekitar yang terkenal akan ramahtamahnya terhadap wisatawan yang lewat di depan rumah penduduk, paket ini memerlukan waktu kurang lebih 1,5 jam, serta paket yang dijual untuk wisatawan seharga harga Rp100.000/ pengunjung atau Rp80.000 per pengunjung dengan MOU,
Paket wisata ini menyajikan paket komplit yang berupa andhong, pemandu wisata, paket industri rumahtangga, agro tani dan plantation, serta paket makanan kudapan.

Walking Tour merupakan salah satu andalan paket wisata untuk wisatawan yang senang mengelilingi desa dengan berjalan kaki dan paket walking tour ini mempunyai durasi selama 2 jam dengan harga Rp30.000/ pengunjung atau 20.000 (MOU). Paket ini terdiri dari pemandu lokal dan donasi. Wisata Menoreh, Paket wisata ini menyajikan keindahan perbukitan Menoreh dengan waktu tempuh 3 jam dengan menapaki jalan setapak dengan pemadangan yang tersaji indah perbukitan menoreh yang ada disisi desa tersebut. Adapun harga yang ditawarkan Rp200.000 per pengunjung serta Rp50.000 (MOU). Adapun yang sudah tercakup dalam paket wisata Menoreh sudah termasuk pemandu lokal, air mineral dan donasi.

Paket Memasak, Paket belajar memasak paket belajar masak yaitu paket yang ditawarkan untuk wisatawan yang akan berkunjung ke desa wisata Candirejo yaitu memasak bersama penduduk lokal. Adapun paket memasak dilakukan selama durasi 3 jam dengan harga yang ditawarkan Rp300.000 per pengunjung dan Rp250.000 (MOU), adapun paket ini sudah termasuk pemandu lokal, dokar, agroplantation, praktis dan bahan untuk memasak, Makan siang, kudapan ringan, teh, serta donasi.

Sepeda Wisata Ontel, tour ini menawarkan kepada wisatawan yang akan mengunjungi Desa Candirejo. Wisatawan dapat diajak memiliki desa wisata menggunakan sepeda ontel. Dalam kunjungan wisata yang ada di desa wisata Candirejo, wisatawan dapat berhenti mengunjungi tempat-tempat yang telah ditentukan antara lain industri rumah tangga, proses kegiatan persawahan, melihat seni gamelan, dan dengan durasi sekitar 3 jam dengan harga yang ditawarkan adalah seharga Rp100.000 per pengunjung atau Rp80.000 (MOU). Paket ini sudah termasuk sepeda lokal get home industri Agro Plantation gamelan simple gamelan snack dan donasi. 
Adanya Homestay, apabila wisatawan ingin menginap dan ingin berinteraksi langsung dengan penduduk desa, maka ada paket homestay yang ditawarkan sebesar Rp300.000 per pengunjung atau Rp200.000 (MOU). Homestay mempunyai kerjasama dengan industri Agro Plantation, simpel gamelan, sarapan, makan malam. Kebudayaan tradisional

Paket menyaksikan serta berinteraksi dengan kebudayaan tradisional masyarakat Candirejo ditawarkan seharga Rp2.000.000 per grup dan Rp1.500.000 (MOU), paket kesenian ini terdiri dari paket kesenian 2 jam termasuk pemandu lokal, makananan tradisional dan donasi. Rafting, Paket wisata ini ditawarkan untuk wisatawan dimana wisatawan tidak perlu khawatir karena akan didampingi pemandu sungai dan paket ini ditawarkan seharga Rp120.000 per pengunjung dan Rp100.000 (MOU). Adapun paket Rafting mempunyai syarat minimal 6 wisatawan yang termasuk perahu, jaket keselamatan, tradisional snack, donasi. Adapun paket rafting ini berlangsung kurang lebih tiga jam. Selain itu adanya Bambu Rafting, Bambu rafting merupakan salah satu paket wisata yang ditawarkan untuk wisatawan, dalam melakukan kegiatan bambu rafting ini menggunakan perahu dari bambu, paket ini ditawarkan menggunakan atau perahu dari bambu ditawarkan Rp. 200.000 per pengunjung dan Rp. 150.000 (MOU). Paket wisata bambu rafting berlangsung kurang lebih 3 jam dengan minimal lima wisatawan termasuk helm, jaket keselamatan, kudapan tradisional dan donasi.

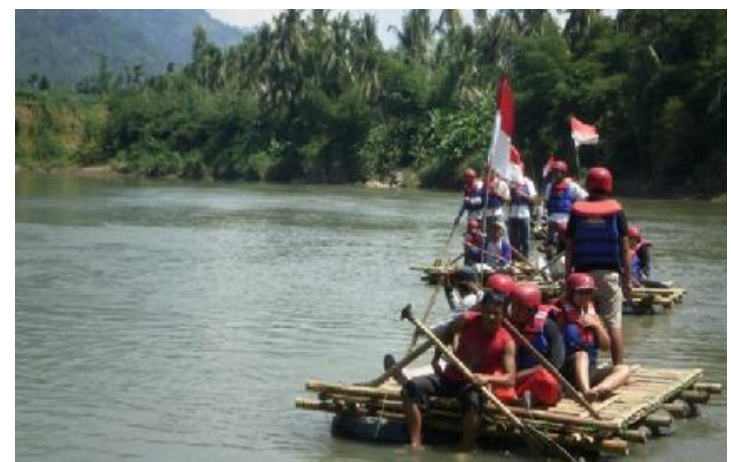

Gambar 2. Bambu Rafting

Sumber: Data primer (2019)

\section{Peningkatan potensi wisata di desa wisata Candirejo dengan menggunakan analisis SWOT.}

Pemetaan desa wisata Candirejo termasuk untuk memfasilitasi pengembangan dan pengendalian penggunaan ideal kawasan wisata desa Candirejo; dalam hal ini, penggunaan dana wisata desa umumnya belum ideal, misalnya, perlu untuk membuat tikar pandan karena banyak panen yang potensial di desa wisata. Selain itu terdapat juga potensi peristirahatan sebelum melakukan kegiatan di Watu Kendil. Terdapat salah satu dusun yang bernama dusun kerekan yang merupakan salah satu dusun sebagai akses utama ke Watu Kendil yang memiliki akses jalan yang kurang bagus sehingga perlu pemataan yang menyeluruh terhadap potensi- potensi yang ada secara menyeluruh.

\section{Analisis SWOT Desa Wisata Candirejo}

Analisis SWOT menurut Kotler \& Keller (2016) menyebutkan bahwa evaluasi menyeluruh terhadap kekuatan, kelemahan, peluang, dan ancamanAnalisis SWOT mempunyai acuan dalam pengembangan desa wisata ke depannya sehingga mampu mengetahui jenis pemberdayaan yang cocok bagai masyarakat desa wisata Candirejo.

Strength (Kekuatan), Dusun Kedung Ombo, Pujungan, Brangkal, Sanjan yang berpotensi meliputi: akomodasi keluarga, agrowisata dan seni tradisional agrotani, wisata naturalistik. Kabupaten Magelang adalah pusat pengembangan pariwisata alam dan area khusus dari kabupaten Sawangan, 
kabupaten Salam, kabupaten Muntilan, kabupaten Srumbung dan kabupaten Borobudur, karena terdapat desa wisata Candirejo yang berbatasan dengan obyek wisata candi Borobudur dan dukungan pemerintah Kabupaten Magelang menjadikan desa Candirejo sebagai tempat pengembangan wisata desa

Weakness (Kelemahan), ada juga beberapa kelemahan di desa-desa wisata, termasuk manajemen yang buruk dan struktur pendukung untuk kegiatan wisata yang masih terbatas pada sumber daya manusia yang tidak siap dan kurangnya modal sosial yang merupakan hambatan bagi pengembangan desa wisata, dikarenakan meningkatnya permintaan pasar yang berkembang sehingga masyarakat belum fokus menggarap desa wisata. Sarana pendukung lebih fokus pada penjualan hasil produksi, daripada menyediakan fasilitas yang baik bagi kepentingan wisata.

Opportunity (Peluang). Adapun peluang untuk menjadikan wisata lokal yang difokuskan pada peningkatan pariwisata, serta adanya desa Candirejo adalah desa wisata pertama di Kabupaten Magelang yang masih sangat luas, pusat wisata desa berjarak sekitar $3 \mathrm{~km}$ dari Candi Borobudur dan merupakan peluang yang tepat untuk dikunjungi. Lebih banyak turis yang berkunjung ke Candi Borobudur sehingga mampu mendatangkan peluang untuk berkunjung ke desa Candirejo sebagai wisata alternatif. Diperlukan lebih banyak koordinasi dengan pihak-pihak lain dalam tur, terutama dengan agen perjalanan sehingga komunitas pariwisata lokal dapat dimasukkan dalam paket wisata dan dapat dijual untuk wisatawan.

Threat (Ancaman). Ancaman terhadap desa Candirejo adalah kontribusi wisatawan yang memilih wisata di Jogja dan Solo. Dibandingkan dengan Kabupaten Magelang, ancaman terbesar adalah peringatan perjalanan bagi wisatawan asing dari negara untuk tidak bepergian ke negara-negara tertentu. Selain itu, persaingan juga semakin ketat, dengan banyak kota wisata bermunculan, serta desa wisata Wanurejo dan sekitarnya juga merupakan ancaman bagi desa wisata Candirejo.

\section{Potensi pengembangan desa wisata Candirejo}

Desa Candirejo memiliki peluang untuk berkembang, karena masyarakat dapat memperkuat paket wisata yang berperan dalam perekonomian masyarakat desa wisata Candirejo antara lain : Jelajahi potensi pariwisata yang ada sehingga dapat dikembangkan, mengemas kembali atraksi yang mungkin dari desa wisata untuk menawarkan wisatawan, mempersiapkan sumber daya masyarakat yang kompeten dan kesiapan masyarakat untuk mendukung pengembangan desa wisata Candirejo, memaksimalkan berbagai potensi yang dimiliki desa serta membuat alternatif dan atraksi yang menarik, menjaga tujuan wisata dengan melakukan promosi wisata, menjalin kerja sama dengan beberapa pihak yang berkompeten di bidang pariwisata, maksimalkan berbagai bantuan dari para pihak dalam pengembangan pariwisata di desa-desa

Desa wisata Candirejo juga memiliki beberapa kekurangan yang harus diatasi, misalnya ancaman yang membutuhkan solusi atas kemungkinan kekurangan desa wisata, termasuk: Keterbatasan sumber daya manusia di desa wisata Candirejo; Desa wisata Candirejo telah beroperasi sejak tahun 2003, tetapi masih belum berlaku dalam banyak hal dalam mendukung pariwisata; Kurangnya koordinasi antara pengrajin yang berbeda untuk menciptakan kecurigaan antara satu pengrajin dan yang lainnya.

Berbagai potensi yang belum dimaksimalkan dapat ditambahkan dengan menambah atraksi dan paket wisata yang menarik serta dikemas dengan apik sehingga membuat desa Candirejo menjadi terkenal serta untuk meningkatkan kualitas desa yang menurun. Selain meningkatkan investasi masyarakat, maka cara tersebut dapat meningkatkan keuangan desa dan menarik investor ke desa wisata Candirejo, sehingga meningkatkan nilai jual tanah serta bangunan yang ada di 
sekitar desa Candirejo. Hal ini sama seperti pendapat dari Antara (2015) bahwa Pembangunan desa wisata harus memperhatikan kemampuan dan tingkat penerimaan masyarakat lokal di mana itu akan dikembangkan desa wisata. Ini untuk tujuan menentukan karakter dan kemampuan

masyarakat yang dapat dimanfaatkan dalam pengembangan desa wisata,menentukan jenis dan tingkat pemberdayaan masyarakat yang sesuai. Untuk belajar tentang penerimaan masyarakat atas kegiatan pembangunan desa

pariwisata: 1) Tidak bertentangan dengan budaya adat istiadat masyarakat Lokal; 2) Pembangunan fisik yang bertujuan untuk meningkatkan kualitas lingkungan desa; 3) memperhatikan unsur lokalitas dan keaslian; 4)Memberdayakan masyarakat desa; 5) Memperhatikan kapasitas dan daya dukung lingkungan.

\section{Melakukan Hubungan Kerjasama Pariwisata}

Melakukan kerjasama dengan DINPORA Kabupaten Magelang DINPORA Kabupaten Magelang mempunyai peranan yang sangat besar bagi pengembangan desa wisata, bantuan berupa modal PNPM menjadi hal yang snagat penting bagi pengembangan desa wisata termasuk halnya kesenian.

Dinas Koperasi dan UKM Kabupaten Magelang berkontribusi besar dalam pelatihan kepada home industri terutama bahayanya penggunaan bahan pengawet makanan. Desa Candirejo mempunyai home insutri slondok ketela sehingga pelatihan ini snagat bermanfaat bagi masyarakat guna menciptakan makanan khas oleh-oleh yang aman dan menyehatkan.

DIPERINDAG

Jawa Tengah memberikan pelatihan yaitu mengenalkan bahaya penggunaan pengawet makanan seperti boraks, formalin, serta melakukan pelatihan dalam sertifikasi makanan yang sesuai dengan kebutuhan pasar, media elektronik dan Media Cetak, dengan promosi melalui sarana elektronik dan cetak sangat membantu bagi penyampaian informasi kepada calon wisatawan, sehingga wisatawan dapat mengetahui paket-paket wisata yang ditawarkan oleh desa wisata Candirejo.

Melakukan kerjasama antara desa dengan travel agent dalam hal ini travelagent akan menggunakan MOU yang berlangsung kurang lebih selama setahun, karena peranan dan fungsi tour and travel adalah mampu mendatangkan rombongan yang nantinya akan mengunjungi desa wisata. Bekerjasama dengan Lembaga Swadaya Masyarakat, kerjasama bantuan desa wisata yaitu dari taman wisata TWC Borobudur serta adanya bantuan finansial dari JIC (Jaoan International Corporation), Pendidikan Menengah Pertama dan Tingkat Atas di Candirejo, Pendidikan di daerah Candirejo yang memiliki sumber daya manusia, yang nantinya akan turut berperan serta dalam kegiatan kesenian seperti gatoloco atau wulang Sunu sehingga apabila ada pertunjukan kesenian Wulang Sunu, maka koperasi Desa akan dicapai hal tersebut sebagai penampil kesenian tradisional yang akan disajikan untuk wisatawan.

Universitas Dian Nuswantoro Semarang menjadi salah satu mitra dalam pengembangan potensi wisata di desa Candirejo. UDINUS memberikan pelatihan dalam mengembangkan aspek hospitality kemudian pengelolaan Homestay sehingga bentuk kerjasama ini merupakan bantuan atau ide dari Universitas Dian Nuswantoro untuk memberikan pelatihan kepada masyarakat sekitar adanya kerjasama dengan pihak lain tentunya menjadikan desa wisata Candirejo mudah dalam mengolah potensi.

\section{Faktor pendukung dan penghambat desa wisata desa Candirejo}

Faktor pendukung dan penghambat desa wisata Candirejo dalam menciptakan masyarakat sekitar, adapaun faktor pendukung dan faktor pengambat antara lain

\section{Faktor pendukung}

Adanya potensi wisata. Desa Wisata Candirejo memiliki banyak potensi alam sehingga dapat dikembangkan sebagai daya tarik untuk dijual kepada wisatawan. Satu- 
satunya kemungkinan untuk pariwisata juga harus diterapkan agar pendapatan masyarakat bisa meningkat.

Letak Strategis, lokasi Desa Wisata Candirejo yang dekat dengan Pusat Pemerintahan, merupakan keuntungan bagi Desa Candirejo. Letak strategis kemudian memudahkan pengunjung untuk mencapai desa wisata Candirejo.

Pemberian Fasilitas. Fasilitas yang diberikan oleh Dinas terkait dengan memberikan pelatihan serta pendampingan yang rutin dilakukan setiap tahunnya.

Tingkat Partisipasi Masyarakat. Sumberdaya manusia diperlukan guna mempercepat proses pengembangan desa wisata, sehingga tingkat partisipasi masyarakat sangatlah diperlukan.

\section{Faktor Penghambat Pengembangan Desa Wisata}

Dana yang terbatas; Sumberdaya manusia yang masih minim; ,Kurang Menguasai Bahasa Asing; Sarana dan Prasarana desa wisata Candirejo; Kebutuhan MCK yang masih terbatas; Tingkat Aksesbilitas; Komunikasi internal dan komunikasi eksternal

\section{Dampak pengembangan desa wisata sebagai model pemberdayaan masyarakat}

Dampak ekonomi mampu menjadikan masyarakat desa wisata Candirejo meningkat dalam taraf pendapatan ekonomi keluarga dengan menyewakan rumah, mengembangkan home industri yang sehat, serta adanya katering desa bagi pemenuhan kebutuhan wisatawan sehingga dapat dikatakan bahwa tingkat kesejahteraan masyarakat menjadi bagus. Umumnya mata pencaharian adalah sebagai petani dan sekarang mendapatkan pekerjaan sampingan seperti pemandu lokal, pekerja seni dan argowisata.

Promosi yang dilakukan oleh desa wisata Candirejo setiap tahun dan adanya penilaian positif dari wisatawan membawa dampak yang sangat bagik bagi kelangsungan desa wisata, terdapat banyak review yang positif yang didapat dari situs dan website pariwisata menjadikan desa Candirejo menjadi dikenal calon wisatawan.

Peningkatan kapasitas ini merupakan tujuan pemberdayaan masyarakat, yang dikemukakan dalam makalah Suryadi (2014) bahwa pemberdayaan adalah proses mengangkat martabat seseorang atau kelompok masyarakat, melalui peningkatkan kemampuan belajar sepanjang hidup (lifelong learning) sebagai proses yang dapat dilakukan dengan memperbaharui pengetahuan, keterampilan, dan keterampilan lain yang bergunakehidupan. Dengan adanya pemberdayaan masyarakat dalam program Desa Wisata, masyarakat mendapat tambahan penghasilan selain pertanian.

\section{SIMPULAN}

Kesimpulan yang dapat disampaikan berdasarkan kegiatan di lapangan seperti wawancara dan analisa data kualitatif antara lain kegiatan yang telah dilakukan kepada masyarakat telah dikatakan berjalan cukup baik dan dibuktikan setelah dilakukan pemberdayaan menjadikandesa tersebut ada pokdarwis, sedangkan saat ini telah terbentuk koperasi desa. Koperasi desa terbentuk dan mempunyai anggota yang dapat menciptakan upaya untuk mengembangkan potensi desa sehingga dapat dijual untuk calon wisatawan. Adapun paket paket wisata yang ditawarkan merupakan gabungan dari home industri, pemandu lokal, serta agro tani. Masyarakat telah menjadikan wisata sebagai penghasilan sampingan selain sebagai petani. Kemudian desa telah melakukan hubungan kerjasama pariwisata dengan berbagai macam instansi diantaranya : DINPORA Kabupaten Magelang, Dinas Koperasi dan UKM Kabupaten Magelang, DIPERINDAG Jawa Tengah, Media elektronik dan Media Cetak, Tour and Travel, Lembaga Swadaya Masyarakat, taman wisata TWC Borobudur serta adanya bantuan finansial dari JIC (Jaoan International Corporation), Pendidikan Menengah Pertama dan Tingkat Atas di Candirejo, akdemisi. Masyarakat desa wisata Candirejo selama pemberdayaan 
mempunyai faktor pendukung antara lain potensi sumberdaya alam, dekat dengan pemeritahan, dan objekwisata, masyarakat desa Candirejo mempunyai potensi untuk bekerjasama dengan pemerintahan, sehingga keberlangsungan objek wisata akan mendapatkan dukungan dari dinas terkait.

\section{REFERENSI}

J, Muljadi, (2012). Kepariwisataan dan Perjalanan. Jakarta: Raja Grafindo Persada

Antara, Made. (2015). Pengelolaan Pariwisata Berbasis Potensi Lokal. Bali : Larasan.

Anwas, Oos M. (2013). Pemberdayaan Masyarakat Di Era Global. Bandung: Alfabeta

Arikunto, Suharsimi. (2003). Manajemen Penelitian. Jakarta: Penerbit Rineka Cipta.

Hadiwijoyo, Surya Sakti. (2012).

Perencanaan Pariwisata Perdesaan Berbasis Masyarakat (Sebuah Pendekatan Konsep). Yogyakarta : Graha Ilmu

Ismayanti. (2013). Pengantar Pariwisata. Jakarta: Grasindo.

Gima, Sugiama (2013). Manajemen Aset Pariwisata Bandung : Guardaya Intimarta.

Kotler, Philip and Kevin Lane Keller (2016). Marketing Managemen, 15th Edition, Pearson Education,Inc

Mustangin, Kusniawati,D., Nufa Pramina Islami, Setyaningrum,B.,Prasetyawati,E. (2017). Pemberdayaan Masyarakat Berbasis Potensi Lokal Melalui Program Desa Wisata Di Desa Bumiaji.Volume 2 No. 1. http://journal.unpad.ac.id/sosioglobal/art icle/view/15282

Peraturan Menteri Pariwisata Republik Indonesia Nomor 29 Tahun 2015 Tentang Rencana Strategis Kementerian Pariwisata Tahun 2015-2019

Septemuryantoro, Syaiful Ade. (2017. Potensi Wisata Budaya Jalur Gula dalam Menunjang Kenaikan Kunjungan Tamu Hotel di Kota Semarang. Vol 13 No 2 https://publikasi.dinus.ac.id/index.php/li te/article/view/1718

Septemuryantoro, Syaiful Ade. (2020.

Potensi Akulturasi Budaya dalam Menunjang Kunjungan Wisatawan di Kota Semarang. Vol 16 No 1 http://publikasi.dinus.ac.id/index.php/lit e/article/viewFile/3434/1880

Sugiyono. (2010). Metode Penelitian Bandung (Pendekatan Kuantitatif, Kualitatif, dan R\&D. Bandung : Alfabeta.

Suryadi, A. (2014). Pendidikan Indonesia Menuju 2025: Outlook: Permasalahan, Tantangan \& Alternatif Kebijakan. Bandung: PT Remaja Rosdakarya

Suwantoro, Gamal . (2004) . Dasar-Dasar Pariwisata (Ed.II) .Yogyakarta: ANDI.

Widayanti, S. (2012). Pemberdayaan Masyarakat: Pendekatan Teoritis. Jurnal Welfare. Vol. 1(1). Hal. 87-102

Undang-Undang Nomor 10 Tahun 2009 tentang Kepariwisataan

Undang- Undang Nomor 90 Tahun 1990 tentang Kepariwisataan

https://www.potensijateng.com/, diakses 1 Oktober 2020). 